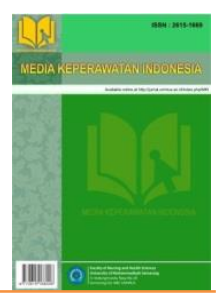

Literature Review

\title{
Well-Being In Breastfeeding Mother
}

\section{Reina Dhamanik $^{1}$, Anggorowati ${ }^{2}$, Sari Sudarmiati ${ }^{3}$}

1 Program Magister Keperawatan, Fakultas Kedokteran, Universitas Diponegoro

2,3 Departemen Ilmu Keperawatan, Fakultas Kedokteran, Universitas Diponegoro

\section{Article Info}

\section{Article History: \\ Accepted Oct 3rd, 2020}

\section{Keywords:}

well-being; breastfeeding; postpartum

\section{PENDAHULUAN}

\section{Kesejahteraan}

(well-being) mempertimbangkan proses yang berbedabeda di dalam membangun penilaian kepuasan yang akan dicapai pada tujuan hidup individu. Individu dengan ekstraversi tinggi cenderung akan bereaksi lebih banyak dan kuat untuk memberi siinyal penghargaan dari lingkungan dan lebih banyak mengalami hal-hal positif dan tercipta kesejahteraan (well-being) (David \& Khesar, 2013). Well-being menjadi salah satu sub komponen dari teori keperawatan Self Transcendence yang dikembangkan
Abstract

Well-being is something that everyone, especially breastfeeding mothers, wants to achieve. Well-being is needed by postpartum mothers to play a new role optimally in the lactation process. The individual experience of breastfeeding is influenced by knowledge, positive affect and a lot of confidence in the breastfeeding process to achieve well-being during the postpartum psychological adaptation process. This study aims to describe the well-being of breastfeeding mothers. Literature review regarding the ell-being of breastfeeding mothers using databases from ProQuest,

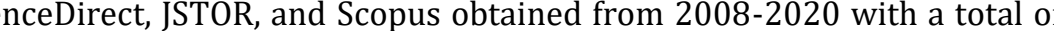
being of postpartum mothers in the breastfeeding process, such as 1) family support, 2) self-efficacy, 3) initiation in the firsttime breastfeeding. 4) positive mood, 5) awareness of self-acceptance, 6) negative obstetric through the management of factors that influence postpartum psychological adaptation as a positive preventive effort in increasing the ability of the lactation process to prevent ineffective breastfeeding.

Corresponding author:

Anggorowati

anggorowati@fk.undip.ac.id

Media Keperawatan Indonesia, Vol 3 No 3, October 2020

e-ISSN: 2615-1669

ISSN: 2722-2802

DOI: https://doi.org/10.26714/mki.3.3.2020.191-207

oleh Reed. Pamela G. Reed menjelaskan dalam teorinya Self Transcendence perawat berperan menjadi fasilitator untuk menggali hal-hal positif dan membangun makna positif dalam diri seseorang sehingga menimbulkan rasa sejahtera (wellbeing) dalam dirinya baik kesejahteraan dari segi fisik, spiritual, dan psikologis (Alligood, 2014).

Well-being dibutuhkan oleh ibu postpartum untuk menjalankan peran baru sebagai seorang ibu secara optimal dalam proses laktasi. Proses menyusui yang tepat dan benar menyebabkan bertambahnya 
produksi air susu sehingga kepuasan dan kenyamanan ibu dan bayi dapat tercipta serta memunculkan perasaan sejahtera (well). Pada saat menyusui terdapat beberapa komplikasi yang menyebabkan ibu merasa tidak nyaman, seperti terjadinya lecet putting susu, adanya bendungan ASI, nyeri pada payudara, yang dapat mengganggu psikologis ibu dalam proses mneyusui (Wen et al., 2015).

Di Indonesia, angka kejadian gangguan psikologis pasca persalinan tidak banyak mengungkap persentase kejadian wellbeing pada ibu postpartum. Ibu melahirkan yang menunjukkan gejala-gejala awal kemunculan gangguan kesejahteraan psikologi berkisar 50-70\% (Diener, 2012). Hal ini didukung penelitian tentang gambaran gangguan psikologis ibu postpartum didapatkan bahwa sebanyak (52,6\%) mengalami gangguan psikologis pasca persalinan (Risnawati \& Susilawati, 2018).

Ibu postpartum berkeinginan melaksanakan aktivitas menyusui dengan nyaman dan lancar, tetapi terkadang gangguan psikologis berupa afek negatif menganggu kenyamanan dalam menyusui, seperti cemas akibat nyeri pada putting, stress, frustasi, takut sakit, cemas, ketidakpercayaan diri hingga depresi (Imelda, 2013).

Nyeri putting pada ibu postpartum primipara adalah hal yang wajar akibat dari terisinya ductus-duktus pada kelenjar air susu sehingga menimbulkan efek ketidaknyamanan serta mempengaruhi kecemasan psikologis, hasil penelitian menunjukkan bahwa faktor predisposisi nyeri putting susu antara lain karena posisi dan kebingungan perlekatan yang kurang tepat $(72,3 \%)$, akibat taunge tie $(23,2 \%$, dan karena kekhawatiran persediaan ASI yang berlebih sebanyak $(4,4 \%)$ (Puapornpong et al., 2017). Hal ini didukung oleh hasil penelitian bahwa proses menyusui yang disertai dengan posisi, durasi, frekuensi, waktu menyusui yang tepat membutuhkan pemahaman yang benar pula pada ibu postpartum khususunya primipara yang harus lebih banyak mengexplore serta belajar tentang proses laktasi sehingga akan membentuk sikap positif selanjutnya akan terjadi perilaku menyusui yang baik (Mbada et al., 2013). Hasil penelitian menyebutkan bahwa meskipun perempuan menyusui bersikap positif terhadap masalah menyusui, defisit dalam pengetahuan acapkali menghambat kapasitas untuk mendorong ibu menyusui secara eksklusif. Pengalaman pribadi dalam menyusui merupakan faktor inspirasi yang unggul yang mempengaruhi pengetahuan, sikap positif dan percaya diri yang besar dalam proses menyusui (Arts et al., 2011).

Kebanggan di dalam ibu menyusui yaitu apabila mampu memberikan ASI Eksklusif pada bayinya secara berkelanjutan, selain itu keunggulan psikologis dari proses menyusui eksklusif adalah membentuk ikatan batin ibu dan anak yang semakin erat yang diharapkan berlangsung seterusnya, sehingga kesejahteraan yang terbina baik yang dimulai melalui proses menyusui (Rusyantia, 2017).

Menyusui dengan benar memiliki manfaat dalam merangsang produksi air susu sehingga ibu tidak merasakan ketidaknyamanan atau nyeri baik dari hisapan bayi pada payudara karena dengan perlekatan yang benar mampu mengeluarkan hormon endorphin. Hormone endorphine merupakan hormone yang dapat meningkatkan perasaan bahagia dan tenang. Dalam keadaan tenang seperti inilah ibu postpartum primipara yang sedang menyusui mampu mempertahankan produksi ASI yang mencukupi bagi bayinya (Cetin et al., 2014).

Tujuan literature review ini adalah untuk mendapat gambaran kesejahteraan (wellbeing) pada ibu yang menyusui. 


\section{METODE}

Metodologi pada penelitian ini adalah literature review. Dalam metode ini dilakukan dengan melakukan analisis tentang fenomena well-being pada ibu postpartum menyusui. Database yang digunakan dalam penyusunan literature review didadapatkan dari database ProQuest, Scientdirect, JSTOR, dan Scopus. Pencarian berfokus pada judul, kata kunci, dan artikel yang sesuai pada jurnal yang telah ditentukan dan diperoleh dari tahun 2010-2020.
Keyword yang digunakan dalam pencarian artikel menggunakan well-being atau kesejahteraan dan Ibu menyusui atau breastfeeding. Hasil penelusuran pada JSTOR 3 artikel, pada ProQuest 2 artikel, dan pada Scopus 2 artikel, dan Sciendirect 3 artikel. Artikel yang dibahas dalam kajian literature yang dapatkan open access, relevan dan free fulltext dengan tema wellbeing pada ibu menyusui. Untuk lebih lengkapnya dapat dilihat pada (Gambar 1).
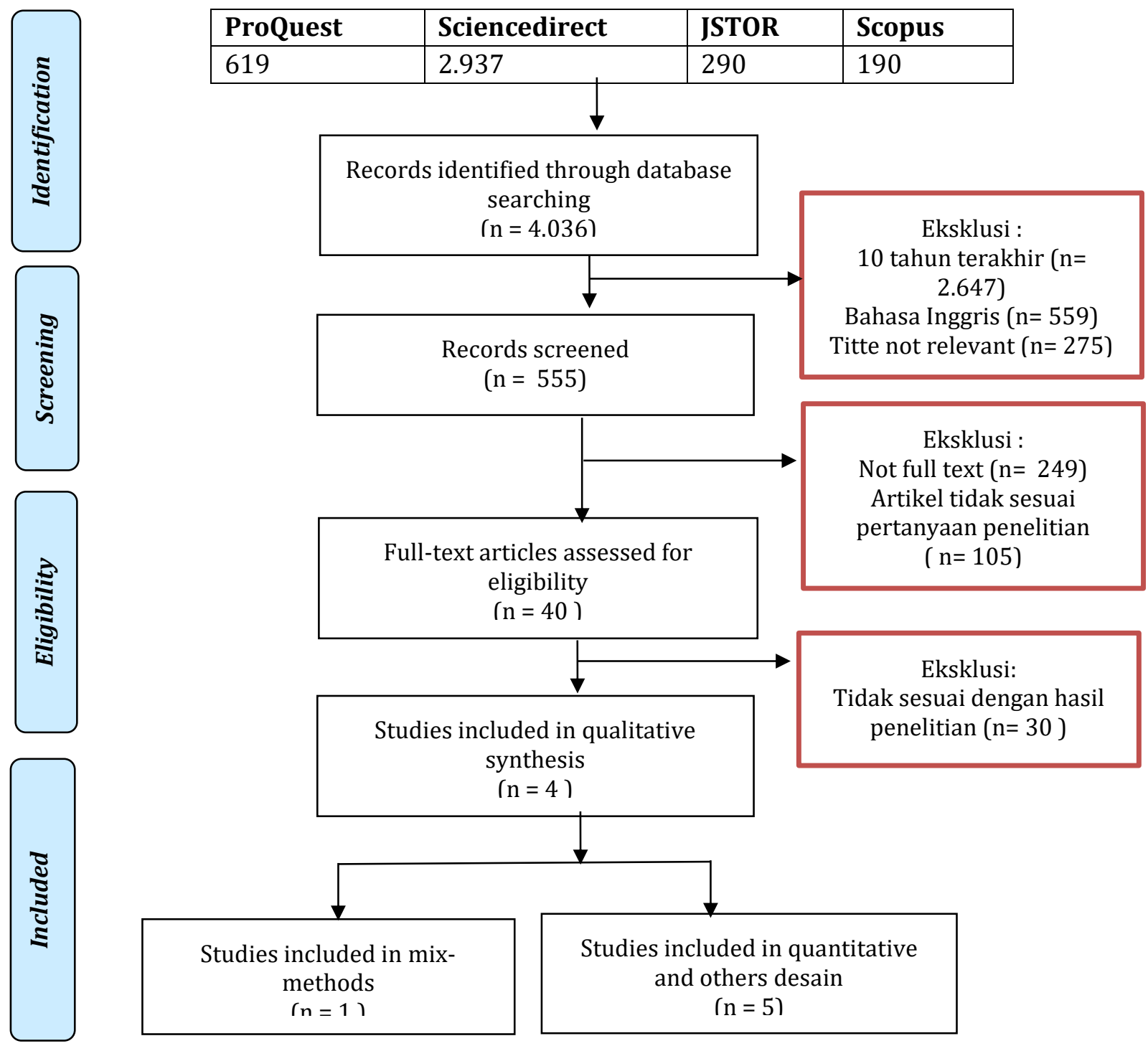

Gambar 1

Algoritma Pencarian Artikel 
HASIL

\section{Perubahan psikologis ibu postpartum dalam proses laktasi}

Perubahan psikologis pasca persalinan pada ibu postpartum terjadi karena karakteristik ibu seperti, usia, pendidikan, ekonomi, status perkawinan, kehamilan/persalinan, serta komplikasi kehamilan/persalinan yang dialami oleh masing-masing ibu postpartum. Hal ini terutama dirasakan bagi ibu postpartum primipara sebagai adaptasi perubahan peran menjadi orang tua dan membutuhkan penyesuaian yang tidak singkat karena ibu perlu menguasai pikiran dan perasaan. Proses penyesuaian sikap dan psikologis ibu postpartum melalui tiga tahapan adaptasi, yaitu taking in, taking hold, dan letting go (Kusumawati et al., 2020). Ibu postpartum yang memahami fungsi dan peran baru akan lebih mudah membentuk kesejahteraan psikologis yang diterimanya serta memiliki keinginan pada proses perawatan diri serta menyusui (Ningsih, 2020).

Hasil literature review menemukan bahwa well-being akan dicapai oleh ibu postpartum apabila proses menyusui mendapatkan dukungan penuh dari keluarga dan tidak ada tekanan serta terdapat faktor-faktor yang berkaitan dengan pembentukan wellbeing ibu postpartum menyusui diantaranya keyakinan diri (self-efficacy), inisiatif menyusui pertama kali (initiation in firstime breasfeeding), penerimaan diri (selfacceptance), pengaruh komplikasi obstetri, dan rendahnya tingkat pengetahuan ibu postpartum.

\section{Kesejahteraan (well-being) ibu postpartum}

Kesejahteraan (well-being) bukan hanya berkisar terhadap baik atau bagusnya kehidupan, tetapi lebih ke aktualisasi potensi dengan tujuan, nilai, dan aspirasi yang membentuk kesejahteraan. Secara ringkas dapat dikatakan bahwa kesejahteraan (well-being) terdiri dari tiga komponen yaitu kepuasan hidup (life satisfaction), suasana hati positif (positive affect) dan suasana hati negatif (negative affect) (Diener, 2012). Keseluruhannya dirangkum sebagai kebahagiaan (happiness). Hasil ini sesuai dengan Diener yang mengatakan bahwa kesejahteraan dibentuk oleh kejadian, pengalaman, dan sumber yang berpengaruh pada kemampuan individu meraih tujuan pribadinya (Diener, 2012).

Wujud kesejahteraan ibu pasca melahirkan yang mampu beradaptasi pada masa postpartum adalah menyusui. Menyusui adalah proses alami bagi seorang ibu untuk menghidupi dan menyejahterakan anak pasca melahirkan. Menurut hasil penelitian bahwa kekuatan yang menyebabkan ibu berhasil menyusui lebih dari enam bulan dan ekslusif adalah kesadaran diri, dukungan, afeksi positif, serta tujuan yang terarah. Ibu yang berhasil menyusui lebih dari enam bulan mempunyai kesadaran diri untuk memaknai ASI. Kesadaran diri yang tinggi terhadap tugas mulia seorang perempuan untuk menyusui, yang timbul sebelum melahirkan, merupakan prediktor baik terhadap suatu keberhasilan. Sedangkan ungkapan afeksi positif yang berhubungan dengan kasih sayang merupakan prediktor signifikan pembentuk kepuasan dan kebahagiaan (well-being) (Wattimena et al., 2012).

\section{Efek well-being pada ibu postpartum yang menyusui}

Proses menyusui diatur oleh hormon prolaktin dan oksitosin. Prolaktin menghasilkan ASI dalam alveolar. Proses bekerjanya prolaktin dipengaruhi oleh lama 
dan frekuensi penghisapan (suckling). Hormon oksitosin disekresi oleh kelenjar pituitary sebagai respon adanya suckling yang akan menstimulasi sel-sel mioepitel untuk mengeluarkan (ejecting) ASI yang diikuti dengan mengalirnya ASI dari simpanan alveoli ke lacteal sinuses sehingga dapat dihisap bayi melalui putting susu. Pelepasan oksitosin selama menyusui meningkatkan relaksasi, menurunkan stress dan ketakutan, menurunkan tekanan darah, menekan perdarahan postpartum dan memfasilitasi involusi uterus (DiezSampedro et al., 2019). Oxytocin (OT) meningkatkan kesejahteraan (well-being) secara umum yang membuat tenang dan lebih baik serta meningkatkan kepercayaan. Hasil penelitian menyatakan bahwa"Wellbeing is a state of absence of mental and physical disease and also of positive emotions and contentment". Perasaan percaya dan memiliki kemampuan adalah faktor-faktor yang dapat meningkatkan well-being. Sebaliknya, ketakutan, kecemasan, mengisolasi diri, khawatir, kurangnya dukungan merupakan kondisi efek dari pelepasan hormone stress yang dapat mengganggu well-being (Ishak et al., 2011).

Faktor psikologis menghambat reflek let down atau reflek pengeluaran ASI. Keadaan psikologis ibu yang cemas dan pikiran yang stress, bingung, kacau dapat menghambat proses implus ke hipotalamus untuk mneghasilkan hormone oksitosin. Produksi ASI yang terus berlangsung, tetapi pengeluaran terhambat akan dapat menyebabkan bendungan ASI (Sembiring, 2017).

\section{Manfaat well-being ibu postpartum yang menyusui}

Word Health Organization (WHO) menyarankan pemberian ASI eksklusif untuk 6 bulan pertama. Manfaat menyusui untuk kesehatan bayi terkait dengan peningkatan berat badan, pencegahan infeksi, serta peningkatan kecerdasan anak. Upaya mempromosikan ASI ekslusif sebagai pilihan pertama untuk bayi oleh peyedia layanan kesehatan dengan memberikan informasi tentang manfaat menyusui tetap diberikan. Penyedia layanan kesehatan seharusnya dan tidak hentinya memberikan dukungan emosional untuk perempuan yang memiliki presepsi tidak dapat menyusui ataupun kesulitan dalam menghadapi proses laktasi untuk dapat merubah pikiran negatif tersebut. Edukasi bahwa ASI merupakan satu-satunya makanan dan minuman utama pada bayi dapat diberikan selalu pada ibu pasca melahirkan serta dorong ibu dalam proses menyusui on demand. Dampak well-being yang didapat perempuan dengan menyusui lebih memiliki positive mood dan lebih sedikit stress/depresi dibandingkan dengan perempuan yang memberikan susu formula (Diez-Sampedro et al., 2019).

Studi telah menemukan korelasi langsung antara sikap positif terhadap menyusui dan praktik Exclusive Breastfeeding (EBF). Sikap positif orang tua terhadap menyusui dilaporkan menjadi komponen penting dalam meningkatkan kesejahteraan (wellbeing) dalam kesehatan pemberian nutrisi untuk bayi (Mbada et al., 2013).

Penting memahami faktor-faktor yang mempengaruhi keputusan Exclusive Breastfeeding (EBF) dimana keyakinan tentang nutrisi terbaik untuk bayi, sikap, pengetahuan, dan kepercayaan serta dukungan keluarga dan tenaga kesehatan sangat terkait dengan praktik menyusui pada ibu pasca persalinan. Ibu pasca persalinan harus memperoleh nutrisi dan istirahat yang cukup karena berpengaruh untuk merangsang produksi ASI yang lebih besar. Hasil penelitian mengungkapkan bahawa minggu pertama setelah melahirkan adalah kondisi yang memicu 
stress para ibu baru dalam menghadapi tantangan tentang menyusui, ketidakadekuatan ketersediaan ASI, pengosongan yang buruk pada payudara, trauma menyusui, serta kelelahan dapat mempengaruhi tingkat stress dan tekanan psikologi ibu yang diakibatkan oleh kondisi bayi seperti, kehilangan berat badan dan munculnya kondisi kuning (jaundice) pada bayi karena ketidakadekuatan proses menyusui (Diez-Sampedro et al., 2019).

Menyusui pada masa bayi hingga 6 bulan pertama eksklusif merupakan indikator kesejahteraan mental seorang anak nantinya hingga sepanjang masa kanakkanak dan remaja awal. ASI merupakan perlindungan yang efektif terhadap faktor resiko penyakit. ASI mengandung lemak yang kaya asam, yang terlibat dalam pertumbuhan otak, neurotransmitter, dan metabolisme. Asam lemak dan metabolisme memainkan peran dalam kesejahteraan (well-being) psikologis/ mental (Ishak et al., 2011). Hasil penelitian menunjukkan bahwa lemak yang kaya asam dan oksitosin pada ASI yang diperoleh dari reflek vagal bayi saat menghisap dan menelan dapat menyebabkan efek anti-stress seperti penurunan tekanan darah dan kadar kortisol yang merangsang berbagai jenis interaksi sosial positif antara ibu dan bayi sehingga meningkatkan relaksasi fisiologis dan well-being ibu (Uvnäs-Moberg \& Petersson, 2015).

Menyusui meningkatkan kesehatan dan kesejahteraan (well-being) ibu postpartum. Bentuk kesejahteraan (well-being) digambarkan dalam kondisi misalnya ditunjukkan dari hasil penelitian kualitatif menemukan bahwa keefektifan pemberian ASI dapat berpengaruh terhadap kualitas tidur, durasi tidur, dan tingkat kelelahan yang dibandingkan dengan ibu yang tidak adekuat dalam memberikan ASI sehingga hal ini mempengaruhi kesejahteraaan fisik (physical well-being) ibu dan menekan perasaan tertekan, perasaan sedih, resiko depresi dan putus asa pada periode menyusui (Kendall-Tackett et al., 2011). Kesejahteraan (well-being) dalam menyusui juga dapat berefek kurang baik pada ibu postpartum. Di negara Barat, ibu muda, etnis kulit putih yang dengan status ekonomi lebih rendah cenderung lebih awal untuk memulai dan mempertahankan menyusui dibandingkan dengan ibu dengan obesitas. Kondisi ini dipengaruhi oleh berbagai hal misalkan kondisi fisik yang mengakibatkan ibu kesulitan dalam proses perlekatan bayi ke payudara dan mempertahankan posisi efektif menyusui sehingga menimbulkan resiko ketidaknyamanan dan terganggunya kesejahteraan psikologis (pcychology wellbeing) pasca persalinan (Swanson et al., 2017).

Hisapan payudara ibu oleh bayi yang benar akan menyebabkan bayi akan meningkatkan kepuasan bayi dan payudara ibu melunak sehingga tidak terjadi pembengakkan payudara (breast engorgement) dan terjadi bendungan ASI. ASI awal mengandung koslostrum yang kaya akan nutrisi dan antibody untuk melindungi bayi. ASI lebih mudah dicerna oleh bayi dibandingkan susu formula, dengan menyusui akan memberikan kesan yang baik bagi ibu dan bayi, karena dengan menyusui terjadi kontak fisik bayi baru lahir dan ibu, merasa lebih aman, hangat, dan nyaman. Kontak fisik dapat meningkatkan produksi oksitosin yaitu hormone yang membantu menghasilkan ASI (Muliarthini et al., 2016).

Motivasi menyusui membuat ibu merasa senang dan bangga karena dapat menyusui bayinya sendiri. Senang dan bangga merupakan bagian dari konsep diri ibu yang positif sebagai ibu, karena ibu dapat berperan optimal dalam perawatan bayinya 
(Kusumawati et al., 2020). Hasil penelitian menunjukkan bahwa kesadaran (mindfulness) ibu menyusui selama periode pengasuhan awal memprediksi dalam meningkatkan kasih sayang diri, perhatian, kepuasan dengan kehidupan, serta terciptanya kesejahteraan subjektif (subjective well-being) (Perez-Blasco et al., 2013).

\section{Hambatan dalam pencapaian well-being ibu menyusui}

Hambatan perempuan dalam menyusui sangat sensitif untuk dijabarkan mengingat menyangkut faktor yang mempengaruhi dilema pengambilan keputusan untuk menyusui, seperti pada kasus ibu tidak diperbolehkan menyusui pada kondisi kasus HIV/AIDS, ibu dengan kejang, ibu dengan gangguan mental, serta ibu yang mengalami trauma pelecehan seksual. Dalam kasus ini seorang konselor laktasi dibutuhkan untuk mengembalikan keyakinan diri dalam menjadi seorang ibu sehingga terwujudnya kesejahteraan (wellbeing) pada ibu postpartum pasca melahirkan. Berikut hasil penelusuran artikel jurnal yang digunakan dalam literature review.

Tabel 1

Sintesis Grid

\begin{tabular}{|c|c|c|c|c|c|c|}
\hline No & Author & Title & Aim & $\begin{array}{c}\text { Design of } \\
\text { study }\end{array}$ & Results & Conclusions \\
\hline 1 & $\begin{array}{l}\text { Konsita } \\
\text { Kuswara } \\
\text { a, }{ }^{*} \text { Tess } \\
\text { Knightc, } \\
\text { Karen J } \\
\text { Campbell } \\
\text { a,b, Kylie } \\
\text { D } \\
\text { Hesketha } \\
\text {,b, } \\
\text { Miaobing } \\
\text { Zhenga,b } \\
\text {, Kristy } \\
\text { A. } \\
\text { Boltond, } \\
\text { Rachel } \\
\text { Laws } \\
\text { (2019) }\end{array}$ & $\begin{array}{l}\text { Breastfeedi } \\
\text { ng and } \\
\text { emerging } \\
\text { motherhoo } \\
\text { d identity: } \\
\text { An } \\
\text { interpretati } \\
\text { ve } \\
\text { phenomeno } \\
\text { logical } \\
\text { analysis of } \\
\text { first time } \\
\text { Chinese } \\
\text { Australian } \\
\text { mothers' } \\
\text { breastfeedi } \\
\text { ng } \\
\text { experiences }\end{array}$ & $\begin{array}{l}\text { Untuk } \\
\text { memahami } \\
\text { pengalaman } \\
\text { pertama } \\
\text { kali ibu-ibu } \\
\text { Australia } \\
\text { yang } \\
\text { memperken } \\
\text { alkan susu } \\
\text { formula } \\
\text { dengan } \\
\text { mereka } \\
\text { yang } \\
\text { mempertah } \\
\text { ankan } \\
\text { exclusive } \\
\text { breasfeedin } \\
\text { g selama } \\
\text { empat } \\
\text { bulan } \\
\text { pertama. }\end{array}$ & $\begin{array}{l}\text { Qualitative } \\
\text { phenomenolo } \\
\text { gy }\end{array}$ & $\begin{array}{l}\text { Masa menyusui dini } \\
\text { adalah masa ketika } \\
\text { semua ibu giat } \\
\text { berjuang dengan ide } \\
\text { dan harapan } \\
\text { menjadi ibu dalam } \\
\text { mencari tujuan } \\
\text { dalam hidup. } \\
\text { Minggu-minggu } \\
\text { pertama setelah } \\
\text { lahir adalah saat- } \\
\text { saat yang membuat } \\
\text { stres } \\
\text { para ibu } \\
\text { menghadapi } \\
\text { tantangan yang } \\
\text { signifikan dengan } \\
\text { menyusui- termasuk } \\
\text { kekhawatiran } \\
\text { pasokan susu yang } \\
\text { dirasakan, proses } \\
\text { pengeluaran yang } \\
\text { buruk, } \\
\text { trauma puting dan } \\
\text { kelelahan akibat } \\
\text { sering menyusui } \\
\text { yang dapat } \\
\text { berdampak negative } \\
\text { terhadap } \\
\text { pengalaman } \\
\text { kesejahteraan } \\
\text { psikologi ibu dan } \\
\text { bayi. }\end{array}$ & $\begin{array}{l}\text { Menyusui adalah } \\
\text { tugas, kewajiban dan } \\
\text { pencapaian.mereka } \\
\text { bangga karena } \\
\text { mereka menunjukkan } \\
\text { bahwa mereka } \\
\text { mampu menyediakan } \\
\text { air susu ibu. } \\
\text { Disisi lain meskipun } \\
\text { mereka memiliki } \\
\text { anggota keluarga } \\
\text { untuk membantu } \\
\text { pekerjaan rumah, } \\
\text { persiapan makan, dan } \\
\text { perawatan bayi, } \\
\text { mereka merasakan } \\
\text { menyusui sangat } \\
\text { melelahkan. } \\
\text { Dukungan menyusui } \\
\text { untuk ibu-ibu } \\
\text { Australia perlu } \\
\text { mempertimbangkan } \\
\text { atau ditingkatkan } \\
\text { sehingga menyusui } \\
\text { merupakan bagian } \\
\text { dari } \\
\text { identitas keibuan } \\
\text { mereka. Profesional } \\
\text { kesehatan memiliki } \\
\text { posisi yang baik } \\
\text { untuk memfasilitasi } \\
\text { proses ini melalui } \\
\text { pemahaman yang }\end{array}$ \\
\hline
\end{tabular}




\begin{tabular}{|c|c|c|c|c|c|c|}
\hline No & Author & Title & Aim & $\begin{array}{c}\text { Design of } \\
\text { study }\end{array}$ & Results & Conclusions \\
\hline & & & & & & $\begin{array}{l}\text { lebih baik tentang } \\
\text { konteks budaya dan } \\
\text { sosial ibu tentang } \\
\text { menyusui. }\end{array}$ \\
\hline 2 & $\begin{array}{l}\text { Julia } \\
\text { Whitleya, } \\
*, 1, \\
\text { Kathryn } \\
\text { Woukb,1, } \\
\text { Anna E. } \\
\text { Bauerc, } \\
\text { Karen } \\
\text { Grewenc, } \\
\text { Nisha C. } \\
\text { Gottfreds } \\
\text { ond, } \\
\text { Samanth } \\
\text { a } \\
\text { Meltzer- } \\
\text { Brodyc, } \\
\text { Cathi } \\
\text { Proppere } \\
\text {, Roger } \\
\text { Mills- } \\
\text { Kooncee, } \\
\text { Brenda } \\
\text { Pearsonc } \\
\text {, Alison } \\
\text { Stuebe } \\
\text { (2020) }\end{array}$ & $\begin{array}{l}\text { Oxytocin } \\
\text { during } \\
\text { breastfeedi } \\
\text { ng and } \\
\text { maternal } \\
\text { mood } \\
\text { symptoms }\end{array}$ & $\begin{array}{l}\text { Penelitian } \\
\text { ini } \\
\text { bertujuan } \\
\text { untuk } \\
\text { mengukur } \\
\text { hubungan } \\
\text { antara } \\
\text { depresi } \\
\text { pascapersal } \\
\text { inan dan } \\
\text { kecemasan, } \\
\text { oksitosin, } \\
\text { serta } \\
\text { menyusui }\end{array}$ & $\begin{array}{l}\text { Cohort study } \\
\text { dan kualitatif }\end{array}$ & $\begin{array}{l}\text { Tidak ada perbedaan } \\
\text { yang signifikan } \\
\text { antara ibu } \\
\text { yang tidak menyusui } \\
\text { pada kunjungan } 2 \\
\text { bulan dan ibu yang } \\
\text { mnegalami depresi. } \\
\text { Sedangkan } \\
\text { tingkat oksitosin } \\
\text { rata-rata lebih tinggi } \\
\text { di seluruh sesi ibu } \\
\text { menyusui } \\
\text { dibandingkan } \\
\text { dengan } \\
\text { ibu yang memberi } \\
\text { susu botol. }\end{array}$ & $\begin{array}{l}\text { Penting untuk } \\
\text { mengamati oksitosin } \\
\text { secara khusus selama } \\
\text { menyusui untuk } \\
\text { menilai perbedaan } \\
\text { oksitosin pada wanita } \\
\text { postpartum } \\
\text { dan terutama yang } \\
\text { berkaitan dengan } \\
\text { gejala "mood" dimana } \\
\text { oksitosin dapat } \\
\text { dikaitkan dengan } \\
\text { gejala suasana hati. } \\
\text { Ini adalah studi } \\
\text { terbesar untuk } \\
\text { menilai oksitosin } \\
\text { selama menyusui } \\
\text { dalam kaitannya } \\
\text { dengan gejala "mood" } \\
\text { ibu, tetapi terbatas } \\
\text { dalam beberapa cara. } \\
\text { Tidak mengherankan, } \\
\text { pola oksitosin } \\
\text { individu selama } \\
\text { menyusui adalah } \\
\text { sangat bervariasi. }\end{array}$ \\
\hline 3 & $\begin{array}{l}\text { D. } \\
\text { Reynolds } \\
\text { *E. } \\
\text { Henness } \\
\text { y† and E. } \\
\text { Polek† } \\
(2013)\end{array}$ & $\begin{array}{l}\text { Is } \\
\text { breastfeedi } \\
\text { ng in } \\
\text { infancy } \\
\text { predictive } \\
\text { of child } \\
\text { mental } \\
\text { well-being } \\
\text { and } \\
\text { protective } \\
\text { against } \\
\text { obesity } \\
\text { at } 9 \text { years of } \\
\text { age? }\end{array}$ & $\begin{array}{l}\text { Penelitian } \\
\text { bertujuan } \\
\text { untuk } \\
\text { melihat } \\
\text { pengaruh } \\
\text { menyususi } \\
\text { terhadap } \\
\text { kesejahtera } \\
\text { an mental } \\
\text { anak } \\
\text { sampai } \\
\text { pada usia } 9 \\
\text { tahun }\end{array}$ & $\begin{array}{l}\text { Cross } \\
\text { sectional dan } \\
\text { cohort studi }\end{array}$ & $\begin{array}{l}\text { Hasilnya } \\
\text { menunjukkan } \\
\text { bahwa, bahkan } \\
\text { setelah } \\
\text { mengendalikan } \\
\text { berbagai variabel } \\
\text { pengganggu, } \\
\text { menyusui pada masa } \\
\text { bayi adalah } \\
\text { prediktor signifikan } \\
\text { mental } \\
\text { kesejahteraan pada } \\
\text { usia } 9 \text { tahun dan itu } \\
\text { merupakan } \\
\text { perlindungan yang } \\
\text { signifikan } \\
\text { faktor terhadap } \\
\text { risiko obesitas pada } \\
\text { usia } 9 \text { tahun. Hasil } \\
\text { penelitian ini } \\
\text { menunjukkan bahwa } \\
\text { jika seorang anak } \\
\text { disusui, } \\
\text { dibandingkan } \\
\text { dengan tidak pernah }\end{array}$ & $\begin{array}{l}\text { Menyusui pada masa } \\
\text { bayi dapat melindungi } \\
\text { terhadap } \\
\text { kesejahteraan mental } \\
\text { yang buruk dan } \\
\text { obesitas di masa kecil. }\end{array}$ \\
\hline
\end{tabular}




\begin{tabular}{|c|c|c|c|c|c|c|}
\hline No & Author & Title & Aim & $\begin{array}{c}\text { Design of } \\
\text { study }\end{array}$ & Results & Conclusions \\
\hline & & & & & $\begin{array}{l}\text { disusui, 26\% lebih } \\
\text { kecil } \\
\text { kemungkinannya } \\
\text { mengalami } \\
\text { permaslahan } \\
\text { psikologis. }\end{array}$ & \\
\hline 4 & $\begin{array}{l}\text { Wendy } \\
\text { Brodribb } \\
* \\
\text { Anthony } \\
\text { Fallont, } \\
\text { Claire } \\
\text { Jackson } \neq \\
\text { and } \\
\text { Desley } \\
\text { Hegney } \\
(2010)\end{array}$ & $\begin{array}{l}\text { The } \\
\text { relationship } \\
\text { between } \\
\text { personal } \\
\text { breastfeedi } \\
\text { ng } \\
\text { experience } \\
\text { and the } \\
\text { breastfeedi } \\
\text { ng attitudes, } \\
\text { knowledge, } \\
\text { confidence } \\
\text { and } \\
\text { effectivenes } \\
\text { s of } \\
\text { Australian } \\
\text { GP } \\
\text { registrars }\end{array}$ & $\begin{array}{l}\text { Penelitian } \\
\text { bertujuan } \\
\text { menjelaska } \\
\text { n } \\
\text { pengalaman } \\
\text { menyusui } \\
\text { pribadi, } \\
\text { pengetahua } \\
\text { n menyusui, } \\
\text { dan } \\
\text { kepercayaa } \\
\text { n diri serta } \\
\text { efektivitas } \\
\text { yang } \\
\text { dirasakan. }\end{array}$ & Cohort study & $\begin{array}{l}\text { Meskipun banyak } \\
\text { yang memiliki sikap } \\
\text { menyusui yang } \\
\text { positif, kekurangan } \\
\text { pengetahuan sering } \\
\text { membatasi kapasitas } \\
\text { mereka untuk secara } \\
\text { efektif mendorong, } \\
\text { mendukung dan } \\
\text { membantu } \\
\text { wanita menyusui } \\
\text { dan } \\
\text { bayinya. Pengalama } \\
\text { n menyusui pribadi } \\
\text { mungkin } \\
\text { menjadi sumber } \\
\text { utama } \\
\text { pengembangan } \\
\text { pengetahuan dan } \\
\text { keterampilan serta } \\
\text { menyusui dan } \\
\text { terkait dengan } \\
\text { peningkatan } \\
\text { pengetahuan, sikap } \\
\text { yang lebih positif } \\
\text { dan kepercayaan diri } \\
\text { yang lebih besar. }\end{array}$ & $\begin{array}{l}\text { Pengalaman } \\
\text { menyusui menjadi } \\
\text { sumber utama } \\
\text { pengembangan } \\
\text { pengetahuan dan } \\
\text { keterampilan } \\
\text { menyusui dan terkait } \\
\text { dengan peningkatan } \\
\text { pengetahuan, sikap } \\
\text { yang lebih positif dan } \\
\text { kepercayaan diri yang } \\
\text { lebih besar. }\end{array}$ \\
\hline 5 & $\begin{array}{l}\text { J Li, GE } \\
\text { Kendall3, } \\
\text { S } \\
\text { Henders } \\
\text { on3, J } \\
\text { Downie3, } \\
\text { L } \\
\text { Landsbo } \\
\text { rough4, } \\
\text { WH } \\
\text { Oddy } \\
\text { (2010) }\end{array}$ & $\begin{array}{l}\text { Maternal } \\
\text { psychosocia } \\
\text { l well-being } \\
\text { in } \\
\text { pregnancy } \\
\text { and } \\
\text { breastfeedi } \\
\text { ng duration }\end{array}$ & $\begin{array}{l}\text { Penelitian } \\
\text { ini } \\
\text { bertujuan } \\
\text { untuk } \\
\text { menguji } \\
\text { apakah } \\
\text { pengalaman } \\
\text { peristiwa } \\
\text { stress } \\
\text { kehidupan, } \\
\text { kontak } \\
\text { sosial / } \\
\text { dukungan } \\
\text { dalam } \\
\text { kehamilan } \\
\text { dan } \\
\text { gangguan } \\
\text { emosional } \\
\text { postpartum } \\
\text { miliki efek }\end{array}$ & Cohort study & $\begin{array}{l}\text { Menyusui secara } \\
\text { eksklusif lazim } \\
\text { dipilih sebagai } \\
\text { tujuan utama } \\
\text { (tidak ada makanan } \\
\text { padat atau susu } \\
\text { lainnya) pada } 6 \\
\text { bulan pertama. } \\
\text { Sebagian besar } \\
\text { faktor psikososial } \\
\text { mulai dari } \\
\text { kehamilan dan } \\
\text { menyusui } \\
\text { secara signifikan } \\
\text { terkait dengan } \\
\text { hubungan } \\
\text { komunikasi dan } \\
\text { dukungan dari } \\
\text { keluarga terutama } \\
\text { suami. }\end{array}$ & $\begin{array}{l}\text { Pengalaman peristiwa } \\
\text { kehidupan yang } \\
\text { penuh tekanan } \\
\text { selama kehamilan } \\
\text { dapat mengganggu } \\
\text { kesejahteraan } \\
\text { psikologi dan } \\
\text { meningkatkan } \\
\text { kemungkinan } \\
\text { penghentian dini } \\
\text { proses menyusui, } \\
\text { sehingga durasi } \\
\text { menyusui dapat } \\
\text { ditingkatkan dalam } \\
\text { proses pemenuhan } \\
\text { nutrisi bayi. }\end{array}$ \\
\hline
\end{tabular}




\begin{tabular}{|c|c|c|c|c|c|c|}
\hline No & Author & Title & Aim & $\begin{array}{l}\text { Design of } \\
\text { study }\end{array}$ & Results & Conclusions \\
\hline & & & $\begin{array}{l}\text { pada durasi } \\
\text { menyusui. }\end{array}$ & & & \\
\hline 6 & $\begin{array}{l}\text { Janice N. } \\
\text { Chincuan } \\
\text { co } \\
(2014)\end{array}$ & $\begin{array}{l}\text { Predictors } \\
\text { of } \\
\text { breastfeedi } \\
\text { ng self- } \\
\text { efficacy and } \\
\text { Initiation in } \\
\text { first-time } \\
\text { breastfeedi } \\
\text { ng mothers }\end{array}$ & $\begin{array}{l}\text { Penelitian } \\
\text { ini } \\
\text { bertujuan } \\
\text { untuk } \\
\text { menganalisi } \\
\text { s dan } \\
\text { menilai } \\
\text { peningkata } \\
\text { n keyakinan } \\
\text { diri } \\
\text { menyusui } \\
\text { pada ibu } \\
\text { yang } \\
\text { pertama } \\
\text { kali } \\
\text { melakukan } \\
\text { proses } \\
\text { laktasi }\end{array}$ & Mix-method & $\begin{array}{l}\text { Artikel membahas } \\
\text { tentang menyusui } \\
\text { memiliki dampak } \\
\text { psikologis dan fisik } \\
\text { yang positif pada ibu } \\
\text { dan bayi. } \\
\text { Penelitian } \\
\text { menunjukkan bahwa } \\
\text { menyusui memiliki } \\
\text { peran penting dalam } \\
\text { pertumbuhan dan } \\
\text { kesejahteraan tidak } \\
\text { hanya bayi, tetapi } \\
\text { pada identitas dan } \\
\text { kesejahteraan } \\
\text { psikologis. ASI telah } \\
\text { terbukti dalam } \\
\text { beberapa penelitian } \\
\text { memiliki banyak } \\
\text { efek positif untuk } \\
\text { ibu menyusui. }\end{array}$ & $\begin{array}{l}\text { Keyakinan diri } \\
\text { merupakan keyakinan } \\
\text { dalam kemampuan } \\
\text { seseorang ujtuk } \\
\text { mengatur dan } \\
\text { melaksanakan } \\
\text { tindakan yang } \\
\text { diperlukan untuk } \\
\text { menghasilkan } \\
\text { kesejahteraan. }\end{array}$ \\
\hline 7 & $\begin{array}{l}\text { Miranda } \\
\text { r. } \\
\text { Waggone } \\
\text { r } \\
(2011)\end{array}$ & $\begin{array}{l}\text { Monitoring } \\
\text { milk and } \\
\text { motherhoo } \\
\text { d: lactation } \\
\text { consultants } \\
\text { and the } \\
\text { dilemmas of } \\
\text { breastfeedi } \\
\text { ng } \\
\text { advocacy1 }\end{array}$ & $\begin{array}{l}\text { Penelitian } \\
\text { yang } \\
\text { dikhususka } \\
\text { n untuk } \\
\text { topik } \\
\text { menyusui di } \\
\text { msayarakat } \\
\text { kontempore } \\
\text { r telah } \\
\text { sebagian } \\
\text { besar } \\
\text { berfokus } \\
\text { pada } \\
\text { pengalaman } \\
\text { ibu, di } \\
\text { tingkat } \\
\text { mikro, } \\
\text { Makalah ini } \\
\text { menambah } \\
\text { literatur } \\
\text { dengan } \\
\text { menganalisi } \\
\text { s sampai } \\
\text { saat ini } \\
\text { belum ada } \\
\text { hubungan } \\
\text { meso-level } \\
\text { dalam } \\
\text { proses } \\
\text { menyusui } \\
\text { secara } \\
\text { mendalam. }\end{array}$ & $\begin{array}{l}\text { Qualitative } \\
\text { study }\end{array}$ & $\begin{array}{l}\text { Terdapatnya faktor- } \\
\text { faktor dalam } \\
\text { pengambilan } \\
\text { keputusan seorang } \\
\text { perempuan untuk } \\
\text { menyusui. Pertama, } \\
\text { dalam hal hambatan } \\
\text { individu untuk } \\
\text { menyusui berkaitan } \\
\text { dengan } \\
\text { sensitifitas terhadap } \\
\text { hambatan fisik dan } \\
\text { psikologis. }\end{array}$ & $\begin{array}{l}\text { Konsultan laktasi, } \\
\text { memiliki potensi } \\
\text { untuk bertindak } \\
\text { sebagai pengatur dan } \\
\text { membentuk sifat } \\
\text { keibuan yang kuat } \\
\text { dan } \\
\text { upaya bersama } \\
\text { dilakukan untuk } \\
\text { meningkatkan } \\
\text { proporsi perempuan } \\
\text { yang menyusui }\end{array}$ \\
\hline
\end{tabular}




\begin{tabular}{|c|c|c|c|c|c|c|}
\hline No & Author & Title & Aim & $\begin{array}{l}\text { Design of } \\
\text { study }\end{array}$ & Results & Conclusions \\
\hline 8 & $\begin{array}{l}\text { Peter } \\
\text { Johannes } \\
\text { Hoffenaa } \\
r^{*} \text { Frank } \\
\text { van } \\
\text { Balen * } \\
\text { Jo } \\
\text { Hermann } \\
\text { s } \\
(2010)\end{array}$ & $\begin{array}{l}\text { The Impact } \\
\text { of Having a } \\
\text { Baby on the } \\
\text { Level and } \\
\text { Content of } \\
\text { Women's } \\
\text { Well-Being }\end{array}$ & $\begin{array}{l}\text { Tujuan } \\
\text { utama } \\
\text { penelitian } \\
\text { ini adalah } \\
\text { untuk lebih } \\
\text { memahami } \\
\text { dampak } \\
\text { dari } \\
\text { memiliki } \\
\text { bayi pada } \\
\text { kesejahtera } \\
\text { an wanita } \\
\text { dengan } \\
\text { memperhati } \\
\text { kan tingkat } \\
\text { dan isi } \\
\text { kesejahtera } \\
\text { an yang } \\
\text { akan } \\
\text { diperoleh. }\end{array}$ & $\begin{array}{l}\text { Qualitative } \\
\text { study }\end{array}$ & $\begin{array}{l}\text { Pengaruh posistif } \\
\text { dan negatif } \\
\text { ditemukan bahwa } \\
\text { kelahiran bayi tidak } \\
\text { secara universal } \\
\text { berdampak pada } \\
\text { tingkat } \\
\text { kesejahteraan } \\
\text { perempuan. Perubah } \\
\text { an dalam konten } \\
\text { well-being } \\
\text { sedang dipelajari } \\
\text { dengan memeriksa } \\
\text { perubahan dalam } \\
\text { cara perempuan } \\
\text { mengalami kegiatan } \\
\text { tertentu } \\
\text { dan interaksi dengan } \\
\text { berbagai mitra } \\
\text { sosial. Banyak ibu } \\
\text { pertama kali } \\
\text { bersemangat untuk } \\
\text { hamil dan berharap } \\
\text { hidup mereka } \\
\text { berubah untuk itu } \\
\text { lebih baik dengan } \\
\text { melahirkan. Namun, } \\
\text { menjadi seorang ibu } \\
\text { mungkin bukan } \\
\text { pengalaman yang } \\
\text { positif untuk semua } \\
\text { perempuan. } \\
\end{array}$ & $\begin{array}{l}\text { Anggapan bahwa } \\
\text { kepuasan hidup, } \\
\text { pengaruh positif, dan } \\
\text { pengaruh negatif } \\
\text { adalah } \\
\text { aspek kesejahteraan } \\
\text { yang berbeda tetapi } \\
\text { saling terkait (Diener } \\
\text { et al. 2003), } \\
\text { penelitian ini memilih } \\
\text { untuk menilai } \\
\text { kesejahteraan } \\
\text { perempuan melalui } \\
\text { beberapa langkah } \\
\text { yang mencakup } \\
\text { berbagai aspek } \\
\text { kesejahteraan, } \\
\text { termasuk didalamnya } \\
\text { penerimaan diri. }\end{array}$ \\
\hline 9 & $\begin{array}{l}\text { K. } \\
\text { Gausia, } \\
\text { D. } \\
\text { Ryder2, } \\
\text { M. Ali4, } \\
\text { C. } \\
(2012)\end{array}$ & $\begin{array}{l}\text { Obstetric } \\
\text { Complicatio } \\
\text { ns and } \\
\text { Well-being: } \\
\text { Experiences } \\
\text { of Women } \\
\text { during } \\
\text { Pregnancy }\end{array}$ & $\begin{array}{l}\text { Penelitian } \\
\text { ini } \\
\text { bertujuan } \\
\text { untuk } \\
\text { mendeskrip } \\
\text { sikan } \\
\text { pengalaman } \\
\text { kehamilan } \\
\text { dan } \\
\text { persalinan } \\
\text { di antara } \\
\text { wanita di } \\
\text { Bangladesh } \\
\text { baik selama } \\
\text { persalinan } \\
\text { normal atau } \\
\text { dengan } \\
\text { komplikasi } \\
\text { dan } \\
\text { memeriksa } \\
\text { hubungan } \\
\text { antara } \\
\text { pengalaman }\end{array}$ & $\begin{array}{l}\text { Quantitative } \\
\text { study }\end{array}$ & $\begin{array}{l}\text { Terdapat hubungan } \\
\text { antara pengalaman } \\
\text { subyektif } \\
\text { persalinan normal - } \\
\text { postpartum yang } \\
\text { memiliki dampak } \\
\text { yang lebih besar } \\
\text { pada keadaan } \\
\text { psikologis ibu } \\
\text { postpartum } \\
\text { daripada } \\
\text { pada metode } \\
\text { persalinan, seperti } \\
\text { instrumentasi atau } \\
\text { intervensi klinis } \\
\text { misalnya episiotomy } \\
\text { dan forsep. Tetapi } \\
\text { kedua hal tersebut } \\
\text { erat kaitannya } \\
\text { dengan penyesuaian } \\
\text { psikologis } \\
\text { postpartum, }\end{array}$ & $\begin{array}{l}\text { Komplikasi obstetrik } \\
\text { yang didefinisikan } \\
\text { secara medis adalah } \\
\text { sebagai } \\
\text { pengalaman negatif } \\
\text { melahirkan yang } \\
\text { berdampak sampai } \\
\text { proses penyesuaian } \\
\text { sebagai seorang ibu. } \\
\text { Pengalaman } \\
\text { persalinan bisa } \\
\text { memberikan } \\
\text { informasi penting } \\
\text { untuk } \\
\text { mengidentifikasi } \\
\text { kemungkinan depresi } \\
\text { pasaca persalinan. }\end{array}$ \\
\hline
\end{tabular}




\begin{tabular}{|c|c|c|c|c|c|c|}
\hline No & Author & Title & Aim & $\begin{array}{c}\text { Design of } \\
\text { study }\end{array}$ & Results & Conclusions \\
\hline & & & $\begin{array}{l}\text { kehamilan- } \\
\text { persalinan } \\
\text { serta } \\
\text { respon } \\
\text { psikologis } \\
\text { kesejahtera } \\
\text { an selama } \\
\text { periode } \\
\text { postpartum. }\end{array}$ & & $\begin{array}{l}\text { terutama proses } \\
\text { laktasi. }\end{array}$ & \\
\hline 10 & $\begin{array}{l}\text { Chidozie } \\
\text { E } \\
\text { Mbada1* } \\
\text { Adekemi } \\
\text { E } \\
\text { Olowook } \\
\text { ere2, Joel } \\
\text { O } \\
\text { Faronbi2 } \\
\text { Folasade } \\
\text { C } \\
\text { Oyinlola- } \\
\text { Aromola } \\
\text { ran1, } \\
\text { Funmilol } \\
\text { a A } \\
\text { Faremi2, } \\
\text { Abiola O } \\
\text { Ogundel } \\
\text { e1, } \\
\text { (2013) }\end{array}$ & $\begin{array}{l}\text { Knowledge, } \\
\text { attitude and } \\
\text { techniques } \\
\text { of } \\
\text { breastfeedi } \\
\text { ng among } \\
\text { Nigerian } \\
\text { mothers } \\
\text { from a } \\
\text { semi-urban } \\
\text { community }\end{array}$ & $\begin{array}{l}\text { Pengetahua } \\
\text { n ibu yang } \\
\text { buruk dan } \\
\text { sikap } \\
\text { negative } \\
\text { terhadap } \\
\text { menyusui } \\
\text { dapat } \\
\text { mempengar } \\
\text { uhi praktik } \\
\text { dan } \\
\text { merupakan } \\
\text { hambatan } \\
\text { untuk } \\
\text { mengoptim } \\
\text { alkan } \\
\text { manfaat } \\
\text { dari inisiatif } \\
\text { ramah- } \\
\text { bayi. Studi } \\
\text { ini menilai } \\
\text { pengetahua } \\
\text { n menyusui, } \\
\text { sikap dan } \\
\text { teknik } \\
\text { postur, } \\
\text { posisi, serta } \\
\text { praktik } \\
\text { menyusui. }\end{array}$ & $\begin{array}{l}\text { Cross } \\
\text { sectional }\end{array}$ & $\begin{array}{l}\text { Hasil penelitian } \\
\text { menunjukkan } \\
\text { pengetahuan baik } \\
\text { menyusui sebesar } \\
\text { 71,3\% responden } \\
\text { dan pengetahuan } \\
\text { sedang sebesar 54\% } \\
\text { yang memiliki sikap } \\
\text { positif. Namun, tidak } \\
\text { ada hubungan yang } \\
\text { signifikan antara } \\
\text { posisi menyusui } \\
\text { dengan tingkat } \\
\text { penetahuan ibu } \\
\text { dalam proses } \\
\text { menyusui. }\end{array}$ & $\begin{array}{l}\text { Ibu-ibu Nigeria } \\
\text { menunjukkan } \\
\text { pengetahuan yang } \\
\text { baik dan sikap positif } \\
\text { terhadap menyusui. } \\
\text { Pengetahuan } \\
\text { berperan penting } \\
\text { dalam memahami } \\
\text { proses menyusui } \\
\text { sehingga tercipta } \\
\text { kepuasan dalam } \\
\text { menyusui. Ibu-ibu } \\
\text { Nigeria rata-rata lebih } \\
\text { nyaman dengan posisi } \\
\text { menyusui dengan } \\
\text { posisi duduk agar } \\
\text { lebih terjalin bonding } \\
\text { attachment antara ibu } \\
\text { dan anak. }\end{array}$ \\
\hline
\end{tabular}

\section{PEMBAHASAN}

Dari hasil literature review terhadap 10 artikel jurnal, dapat dijelaskan bahwa wellbeing berperan pada kondisi psikologis ibu menyusui. Ibu postpartum rentan berpotensi mengalami beberapa komplikasi fisik dan gangguan psikologis, yang dapat mempengaruhi tercapainya kesejahteraan (well-being) pasca melahirkan. Ibu postpartum yang memiliki well-being tinggi seharusnya memiliki perasaan bahagia, percaya diri dalam menjalani perannya sebagai seorang ibu khususnya pasa dproses menyusui (breastfeeding), mendapatkan dukungan dan merasa puas akan kehidupan yang dijalaninya.

Analisa sintesa pada literature review mengungkap faktor yang mempengaruhi well-being ibu menyusui, yaitu 1) dukungan keluarga (family support), 2) keyakinan diri ibu (self-efficacy), 3) inisiatif menyusui pertama kali (initiation in firsttime breasfeeding), 4) positive mood (suasana positif), 5) kesadaran akan penerimaan diri 
menjadi ibu (self-acceptance), 6) negative obstetric experience (pengalaman buruk obstetric), 7) knowledge (pengetahuan ibu) dengan dua komponen evaluasi yang dapat terbentuk dari well-being ibu postpartum, yaitu good well-being atau bad well-being yang dapat menjadi pertimbangan pemberian penatalaksanaan diagnosis keperawatan dalam proses laktasi pasca melahirkan.

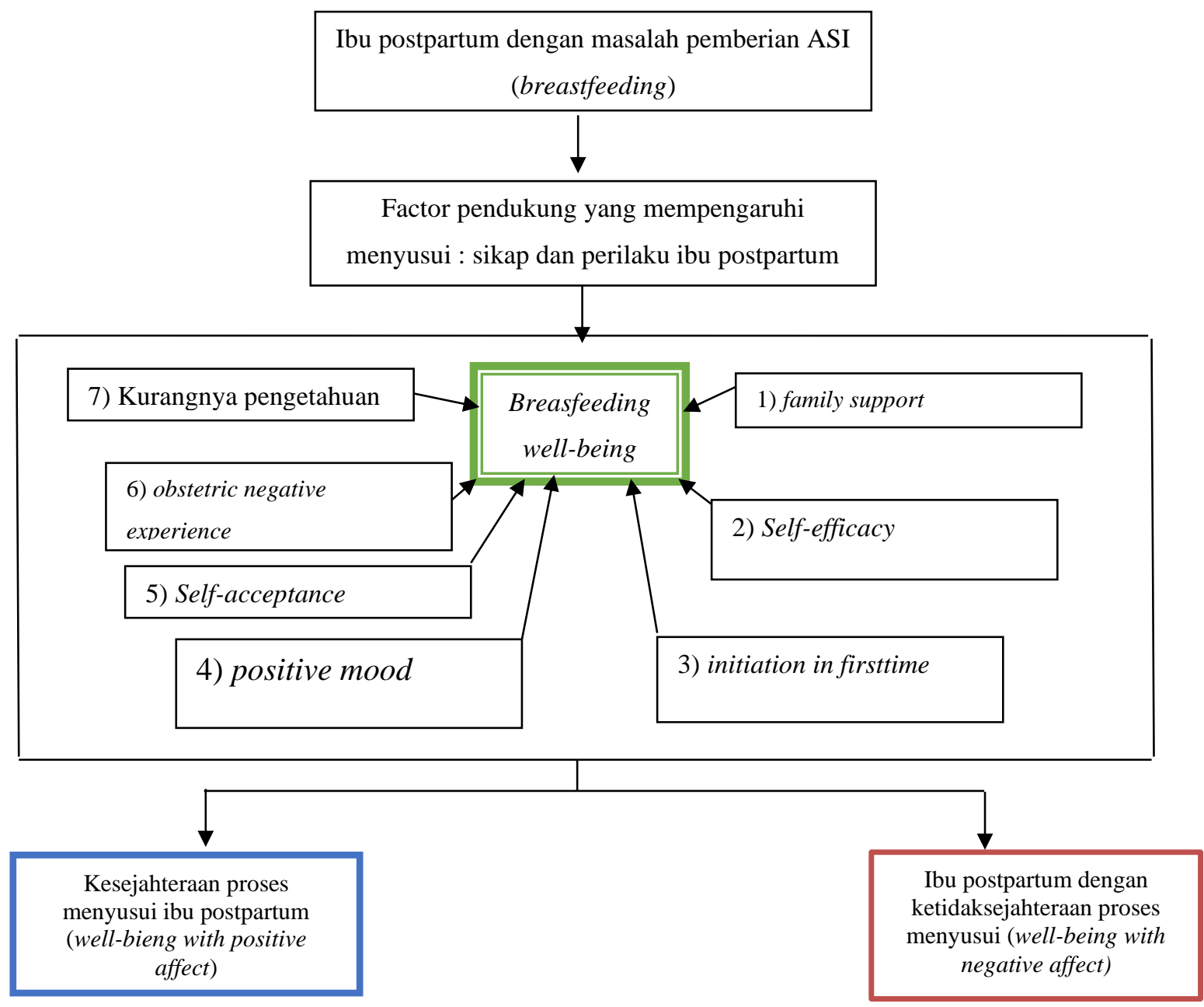

Gambar 2

Analisa sintesis well-being ibu menyusui

Pembahasan tentang gambaran well-being ibu postpartum yang menyusui terangkum dalam poin-poin berikut :

\section{Dukungan keluarga (family support) dalam proses laktasi}

Peran keluarga dalam proses menyusui dapat memberikan dukungan berupa dukungan informasi, instrumental, penghargaan dan dukungan emosional yang merupakan faktor eksternal yang berpengaruh terhadap keberhasilan kesejahteraan psikologis ibu postpartum. Semakin besar dukungan yang dilakukan maka semakin besar pula kemampuan dan capaian kesejahteraan untuk terus bertahan dalam proses menyusui. sKepercayaan diri ibu postpartum dalam mencapai well-being sangat diperlukan salah satunya sebagai sumber energi dalam membentuk 
psikologis yang positif. Dukungan keluarga erat kaitan dengan kondisi well-being ibu pasca melahirkan (Dib et al., 2020). Wellbeing didefinisikan kesejahteraan yang melibatkan pengalaman positif dan membangun fungsi positif seseorang seperti, kebahagiaan dan kemampuan individu memaknai hidupnya serta menjalani kehidupan dengan baik sesuai fungsinya, sehingga dapat disimpulkan bahwa jika terdapat permasalahan psikologi dapat mempengaruhi tercapainya well-being selama adaptasi postpartum (Rowlands \& Redshaw, 2012). Dukungan keluarga dapat menentukan keberhasilan atau kegagalan menyusui, terlebih dukungan suami akan menciptakan kenyamanan pada ibu sehingga akan mempengaruhi produksi ASI (Sari \& Islamiah, 2020).

\section{Penerimaan diri (self-acceptance) perubahan psikologis ibu postpartum}

Perubahan fisiologis pasca persalinan dapat berdampak negatif terutama pada psikologis well-being. Ibu postpartum dalam menjalankan kehidupan sehari-hari, khusunya proses menyusui apabila tidak disertai dengan sikap penerimaan diri (selfacceptance) akan tercipta sisi lain dari kehadiran anggota baru dalam kehidupan seorang perempuan yang tidak selamanya merupakan bentuk kebahagiaan karena membutuhkan sebuah penyesuaian. Proses penyesuaian diri dalam mencapai wellbeing ibu postpartum tentunya sangat berpengaruh terhadap pemulihan kesehatan serta kemampuan dalam menjalani peran barunya dengan baik serta mampu menerima perubahan psikologis yang dialami (Özbiler \& Beidoğlu, 2020; Palupi, 2020).

\section{Kurangnya initiation in firsttime breastfeeding}

Hasil penelitian menyebutkan bahwa banyak pasangan baru tidak percaya diri pada kemampuan yang dimiliki dalam memenuhi perubahan peran tanggung jawab sebagai orangtua, terdapat pengaruh antara keyakinan diri dalam menentukan well-being psikologis sebagai orangtua. Keyakinan dapat menentukan rasa percaya diri dan bentuk kebahagiaan dalam menentukan kulitas hidup yang akan dijalani oleh ibu postpartum terutama pada proses menyusui (Azmoude et al., 2015).

\section{Keyakinan diri (self-eficacy) akan kemampuan menyusui}

Menyusui merupakan proses alami bagi seorang ibu untuk menghidupi dan mensejahterakan anak pasca melahirkan. Keberhasilan menyusui menjadi perhatian nasional, karena capaian pemberian ASI masih belum memenuhi target. Pemahaman laktasi yang jauh dari kebenaran tentu memprihatinkan karena keadaan ini menyangkut kesehatan dan well-being antara ibu dan bayi dalam proses menyusui. Kekuatan dalam mencapai wellbeing pada ibu menyusui antar lain kesadaran diri, dukungan, afek positif (rasa sayang, rasa bahagia, ataupun rasa bangga), keyakinan diri, tujuan serta keyakinan diri (self efficacy), sehingga produksi ASI akan optimal. Well-being dibentuk oleh kejadian atau pengalaman dan sumber yang berpengaruh pada kemampuan individu dalam meraih tujuan pribadi (Wattimena et al., 2012). Dalam proses menyusui diduga bahwa aktivasi produksi neuropeptide opioid oleh hisapan pada putting dapat memicu afek positif seorang ibu, dimana ibu akan menunjukkan rasa bangga, bahagia, puas, lega, cinta, sayang, yang berperan terhadap peningkatan hormone endorphin yang mengatur respon terhadap stress sehingga psikologis ibu menyusui lebih tenang dan rileks (Kusumaningrum \& Aris, 2016). Self-efficacy ibu berkembang dan meningkat seiring dengan ekebrhasilan ibu dalam menjalankan tugas-tugas sulit dalam perawatan bayi. Berdasarkan hasil penelitian kepuasan orangtua terutama ibu adalah dengan rasa senang atas keyakinan diri yang didapat dari perannya sebagai ibu yang harus menyusui dan menjadi seorang orang tua bagi bayinya. Ibu dengan keyakinan diri yang kuat cenderung mmebuat rencana tindakan saat melakukan perawatan bayi terutama proses laktasi, 
dimana ibu harus bangun di tengah malam demi memberikan air susu kepada bayinya. Keyakinan diri ibu yang negative didapat akibat pengaruh stress, kecemasan, bahkan depresi pasca melahirkan dan ketidaknyamanan serta kelalahan yang mempengaruhi kesejahteraan yang berpotensi menrunkan efikasi diri (Botha et al., 2020).

\section{Pengalaman obstetri ibu postpartum}

Ibu postpartum dengan riwayat persalinan lama dan komplikasi pasca persalinan menunjukkan permasalahan dalam menerima perawatan diri. Tingkat ketahanan dan penerimaan ibu terhadap proses dan komplikasi pasca persalinan sangat bervariasi. Beberapa ibu melihatnya sebagai bagian dari proses persalinan, sementara sebagian menganggap sebagai trauma psikologis yang substansial dengan bereaksi marah, memiliki perasaan tertekan, suasana hati bahkan pikiran yang tidak peduli, bahkan hingga munculnya depresi. Hasil penelitian sebelumnya mengungkapkan bahwa salah satu yang memicu trauma psikologis seperti nyeri persalinan yang dapat mempengaruhi resiko depresi ibu postpartum sekaligus berdampak dalam perawatan diri dan bayi. Resiko gangguan depresi ibu postpartum dapat memunculkan perasaan yang tidak menyenangkan dan berdampak pada perkembangan bayi serta kesejahteraan (well-being) selama proses adaptasi ibu postpartum. Temuan ini memberikan kesan yang akut bahwa nyeri persalinan memainkan peran penting di bagian akhir terhadap gangguan perasaan dalam mencapai kesejahteraan (well-being) postpartum (Asif et al., 2020; Lim et al., 2020).

\section{Kurangnya pengetahuan akan proses menyusui}

Pengetahuan perawatan pasca persalinan memiliki peran penting dalam mengurangi komplikasi dan kesejahteraan (well-being) bagi ibu dan bayi. Hasil penelitian menjelaskan bahwa persentasi pengetahuan dalam mengenali nutrisi yang diperlukan bayi berkisar $46 \%$ dan masih perlunya peningkatan pengetahuan pada konsep konsep pemberian air susu, frekuensi menyusui dan perawatan payudara. Peningkatan pengetahuan diamati dengan pada tingkat pendidikan ibu, status obstetrik, dan usia ibu postpartum. Pengetahuan mengantarkan ibu dalam proses perawatan pasca persalinan yang bertujuan untuk meningkatkan kesejahteraan psikologis dan fisik ibu dan bayi serta memperkuat ketrampilan dalam pemberian nutrisi bayi pada proses menyusui. Telaah hasil penelitian mengungkapkan bahwa hampir sepertiga ibu postpartum mengungapkan ketidakmampuan untuk menyusui yang mempengaruhi terciptanya well-being serta sebanyak $19 \%$ ibu belum dapat menjelaskan bagaimana menjalani masa postpartum terlebih ibu primipara pada proses pasca melahirkan. Pengetahuan yang benar tentang perawatan bayi baru lahir harus dipastikan oleh tenaga kesehatan, keluarga dan lingkungan untuk menghindari keterlambatan penanganan adanya gangguan pada bayi (Beraki et al., 2020; Sandhya \& Rojana, 2015).

\section{SIMPULAN}

Berdasarkan analisa yang telah dilakukan oleh penulis, disimpulkan bahwa wujud kesejahteraan ibu pasca melahirkan yang mampu beradaptasi pada masa postpartum adalah menyusui. Ibu postpartum rentan berpotensi mengalami beberapa komplikasi fisik dan gangguan psikologis, yang dapat mempengaruhi tercapainya kesejahteraan (well-being) pasca melahirkan. Kekuatan dalam mencapai well-being pada ibu menyusui antar lain kesadaran dan kepercayaan diri, dukungan, afek positif untuk tercapainya kepuasan hidup (life satisfaction). Kepercayaan diri ibu postpartum dalam mencapai well-being sangat diperlukan sebagai sumber energi dalam membentuk psikologis yang positif. Well-being didefiniskan kesejahteraan yang 
melibatkan pengalaman positif dan membangun fungsi positif seseorang.

\section{UCAPAN TERIMAKASIH}

Penulis mengucapkan terimakasih kepada semua pihak yang telah mendukung dalam penulisan studi literatur ini.

\section{REFERENSI}

Alligood, M. R. (2014). NUrsing theorists and their work. In Elsevier (8th ed.). Elsevier. https://doi.org/10.2174/9781681087450118 0101

Arts, M., Geelhoed, D., De Schacht, C., Prosser, W., Alons, C., \& Pedro, A. (2011). Knowledge, beliefs, and practices regarding exclusive breastfeeding of infants younger than 6 months in Mozambique: A qualitative study. Journal of Human Lactation, 27(1), 25-32. https://doi.org/10.1177/0890334410390039

Asif, S., Mulic-Lutvica, A., Axfors, C., Eckerdal, P., Iliadis, S. I., Fransson, E., \& Skalkidou, A. (2020). Severe obstetric lacerations associated with postpartum depression among women with low resilience - a Swedish birth cohort study. BJOG: An International Journal of Obstetrics and Gynaecology,

$1-9$. https://doi.org/10.1111/1471-0528.16271

Azmoude, E., Jafarnejade, F., \& Mazlom, S. R. (2015). The Predictors for Maternal Self-efficacy in Early Parenthood. Journal of Midwifery \& Reproductive Health, 3(2), 368-376. https://doi.org/10.22038/JMRH.2015.4050

Beraki, G. G., Tesfamariam, E. H., Gebremichael, A., Yohannes, B., Haile, K., Tewelde, S., \& Goitom, S. (2020). Knowledge on postnatal care among postpartum mothers during discharge in maternity hospitals in Asmara: A crosssectional study. BMC Pregnancy and Childbirth, 20(1), 1-10. https://doi.org/10.1186/s12884019-2694-8

Botha, E., Helminen, M., Kaunonen, M., Lubbe, W., \& Joronen, K. (2020). Mothers' parenting selfefficacy, satisfaction and perceptions of their infants during the first days postpartum. Midwifery, $\quad 88, \quad 102760$. https://doi.org/10.1016/j.midw.2020.102760

Cetin, I., Assandro, P., Massari, M., Sagone, A., Gennaretti, R., Donzelli, G., Knowles, A., Monasta, L., \& Davanzo, R. (2014). Breastfeeding during pregnancy: Position paper of the italian society of perinatal medicine and the task force on breastfeeding, Ministry of Health, Italy. Journal of Human Lactation, $30(1)$

20-27. https://doi.org/10.1177/0890334413514294

David, S., \& Khesar, J. (2013). The Oxford Handbook of Happiness (S. A. David, I. Bonuwell, \& A. C. Ayers (eds.); I). Oxfort University Press.

Dib, S., Fewtrell, M., Wells, J. C. K., \& Shukri, N. H. M. (2020). The Influence of Hospital Practices and Family Support on Breastfeeding Duration, Adverse Events, and Postnatal Depression Among First-Time Mothers. 16, 89-97.

Diener, E. (2012). Subjective well-being and security. In Springer Dordrecht Heidelberg (Vol. 46). Springer Dordrecht Heidelberg. https://doi.org/10.1007/978-94-007-2278-1

Diez-Sampedro, A., Flowers, M., Olenick, M., Maltseva, T., \& Valdes, G. (2019). Women's Choice Regarding Breastfeeding and Its Effect on Well-Being. Nursing for Women's Health, 23(5), 383-389. https://doi.org/10.1016/j.nwh.2019.08.002

Imelda, J. (2013). Perbedaan Subjective Well Being Ibu ditinjau dari Status Bekerja Ibu. Jurnail Ilmiah Mahasiswa Universitas Surabaya, 2(1), 1-16.

Ishak, W. W., Kahloon, M., \& Fakhry, H. (2011). Oxytocin role in enhancing well-being: A literature review. Journal of Affective Disorders, 130(1-2), $1-9$. https://doi.org/10.1016/j.jad.2010.06.001

Kendall-Tackett, K., Cong, Z., \& Hale, T. W. (2011). The Effect of Feeding Method on Sleep Duration, Maternal Well-being, and Postpartum Depression. Clinical Lactation, 2(2), 22-26. https://doi.org/10.1891/2158053118070115 93

Kusumaningrum, A. T., \& Aris, A. (2016). Efektifitas Kombinasi Stimulasi Oksitosin dan Endorfin Massage terhadap Kejadian Bendungan ASI pada Ibu Post Partum Primipara. Jurnal Surya, 08(03), 31-37.

Kusumawati, P. D., Damayanti, F. O., Wahyuni, C., \& Setiawan, A. (2020). Analisa Tingkat Kecemasan Dengan Percepatan Pengeluaran ASI Pada Ibu Nifas. Journal for Quality in Women's Health, 3(1), 101-109. https://doi.org/10.30994/jqwh.v3i1.69

Lim, G., Lasorda, K. R., Farrell, L. M., McCarthy, A. M., Facco, F., \& Wasan, A. D. (2020). Obstetric pain correlates with postpartum depression symptoms: A pilot prospective observational study. BMC Pregnancy and Childbirth, 20(1), 114. https://doi.org/10.1186/s12884-02002943-7

Mbada, C. E., Olowookere, A. E., Faronbi, J. O., Oyinlola-Aromolaran, F. C., Faremi, F. A., Ogundele, A. O., Awotidebe, T. O., Ojo, A. A., \& Augustine, O. A. (2013). Knowledge, attitude 
and techniques of breastfeeding among Nigerian mothers from a semi-urban community. BMC Research Notes, 6(1), 1-8. https://doi.org/10.1186/1756-0500-6-552

Muliarthini, N. W., Sutjana, D. P., \& Adiatnika, I. P. G. (2016). Use of Redesign Breasfeeding Pillow to Improve Motivation of Breasfeeding Mothers and babies Satidfaction, Reduce Fatigue and Muskuloskeletal Complaints on Postpartum. The Indonesian Journal of Egonomic, 2(2).

Ningsih, S. (2020). Konseling Parenting Sebagai Upaya Menurunkan Kejadian Gangguan Psikologis Post Partum Counseling of Parenting To Reduce Post Partum Psychological Disorder. Indonesian Journal On Medical Science, 7(2), 120-124.

Nisa, S. H. (2006). Gambaran subjective well-being pada ibu yang mengalami baby blues. Jurnal Keperawatan UII.

Özbiler, Ş., \& Beidoğlu, M. (2020). Maternal subjective well-being intervention effects: Subjective well-being and self-perception of the parental role. Current Psychology, 39(3), 1020-1030. https://doi.org/10.1007/s12144018-9818-6

Palupi, P. (2020). Studi Fenomenologi: Pengalaman Primipara Saat Mengalami Depresi Postpartum. Jurnal Persatuan Perawat Nasional Indonesia (JPPNI), 4(2), 81. https://doi.org/10.32419/jppni.v4i2.181

Perez-Blasco, J., Viguer, P., \& Rodrigo, M. F. (2013). Effects of a mindfulness-based intervention on psychological distress, well-being, and maternal self-efficacy in breast-feeding mothers: Results of a pilot study. Archives of Women's Mental Health, 16(3), 227-236. https://doi.org/10.1007/s00737-013-0337-z

Puapornpong, P., Raungrongmorakot, K., Laosooksathit, W., Hanprasertpong, T., \& Ketsuwan, S. (2017). Comparison of Breastfeeding Outcomes between Using the Laid-Back and Side-Lying Breastfeeding Positions in Mothers Delivering by Cesarean Section: A Randomized Controlled Trial. Breastfeeding Medicine, 12(4), 233-237. https://doi.org/10.1089/bfm.2016.0193

Risnawati, \& Susilawati, D. (2018). Gambaran kejadian post partum blues pada ibu nifas
Tahun 2018. Jurnal Kesehatan Panca Bhakti Lampung, VI(2).

Rowlands, I. J., \& Redshaw, M. (2012). Mode of birth and women's psychological and physical wellbeing in the postnatal period. $B M C$ Pregnancy and Childbirth Journal, 12. https://doi.org/10.1186/1471-2393-12-138

Rusyantia, A. (2017). Hubungan Teknik Menyusui Dengan Keberhasilan Menyusui Pada Bayi Usia 0-6 Bulan Yang Berkunjungdi Puskesmas Kedaton Tahun 2015. 11(2), 90-94.

Sandhya, T., \& Rojana, D. (2015). Knowledge on Postnatal Care Among Postnatal Mothers. Saudi Journal of Medical and Pharmaceutical Sciences, 1(4), 87-92.

Sari, W. I., \& Islamiah, D. (2020). Hubungan Antara Dukungan Keluarga Dengan Perilaku Ibu Dalam Pemberian ASI Eksklusif. Borneo Journal of Medical Laboratory Technology, 2(2), 155160.

Sembiring, I. (2017). Efektivitas hypnobreastfeeding pada ibu menyusui dengan kecukupan air susu ibu. Politeknik Kesehatan Kemenkes.

Swanson, V., Keely, A., \& Denison, F. C. (2017). Does body image influence the relationship between body weight and breastfeeding maintenance in new mothers? British Journal of Health Psychology, 22(3), 557-576. https://doi.org/10.1111/bjhp.12246

Uvnäs-Moberg, K., \& Petersson, M. (2015). Oxytocin, a mediator of anti-stress, well-being, social interaction, growth and healing. Zeitschrift Fur Psychosomatische Medizin Und Psychotherapie, 51(1), 57-80. https://doi.org/10.13109/zptm.2005.51.1.57

Wattimena, I., Susanti, N. L., \& Marsuyanto, Y. (2012). Kekuatan Psikologis Ibu untuk Menyusui. Kesmas: National Public Health Journal, 7(2), 56. https://doi.org/10.21109/kesmas.v7i2.63

Wen, L., Hilton, G., \& Carvalho, B. (2015). The impact of breastfeeding on postpartum pain after vaginal and cesarean delivery. Journal of Clinical Anesthesia, 27(1), 33-38. https://doi.org/10.1016/j.jclinane.2014.06.01 0 